ISSN 1392-3196 / e-ISSN 2335-8947

Zemdirbyste-Agriculture, vol. 101, No. 2 (2014), p. 185-192

DOI 10.13080/z-a.2014.101.024

\title{
Bacteria with a broad-spectrum of antagonistic activity against pathogenic fungi of cereals
}

\author{
Simonas SAKALAUSKAS ${ }^{1,3}$, Audrius KAČERGIUS ${ }^{2}$, Dalia JANUŠAUSKAITÉ ${ }^{3}$, \\ Donaldas ČITAVIČIUS ${ }^{1}$ \\ ${ }^{1}$ Vilnius University \\ M. K. Čiurlionio 21/27, Vilnius, Lithuania \\ E-mail: simonas.sakalauskas@gmail.com \\ ${ }^{2}$ Vokè Branch, Lithuanian Research Centre for Agriculture and Forestry \\ Žalioji 2, Trakų Vokè, Vilnius, Lithuania \\ ${ }^{3}$ Institute of Agriculture, Lithuanian Research Centre for Agriculture and Forestry \\ Instituto 1, Akademija, Kèdainiai distr., Lithuania
}

\begin{abstract}
Prevalent fungal pathogens of cereals in Lithuania belong to diverse systematic groups and this makes search for microbial biocontrol measures rather difficult. One of the options would be broad-spectrum biocontrol agents. In order to find these, 1037 seed-borne and 11 soil-borne rhizosphere pathogenic fungi were isolated and their systematic position determined. Fungi of genera Alternaria, Ulocladium, Fusarium were dominant, with Bipolaris sorokiniana and Drechslera being isolated at significantly lower rates. Forty two of these pathogenic micromycetes and type strain of Gaeumannomyces graminis var. graminis DSM1463 were used as test cultures in antagonistic trials involving 214 microbial isolates from agricultural soil. Ten bacterial strains were found to express antagonistic in vitro activity against more than half of the selected pathogenic fungi. $16 \mathrm{~S}$ ribosomal deoxyribonucleic acid (rDNA) analysis showed 5 of these bacterial strains to be related to Bacillus subtilis species: 1 - B. thuringiensis, 1 - B. mycoides/B. pseudomycoides, 2 - Serratia odorifera and 1 - Pseudomonas spp.
\end{abstract}

Key words: antibiosis, bacteria, broad-spectrum antagonism, cereal diseases, pathogenic micromycetes.

\section{Introduction}

In Lithuania, the main part of cereal crop harvest loss is caused by pathogenic micromycetes. Of these, only the pathogenic micromycetes which affect the upper part of plant can be effectively controlled by chemical means. The activity of root-zone pathogens usually depends on the resistance level of a plant variety and favour of abiotic conditions for disease development, with some pathogens being affected by fungicidal seed dressing or mechanical destruction of the inoculum.

Root-zone pathogens of cereal crops are soilborne or seed-borne. The manifestation and severity of diseases caused by these pathogens are highly dependent on meteorological conditions, which are uncertain in Lithuania, and therefore it is impossible to name one most severe disease. Research findings (Kačergius, Mačkinaitè, 2005; Mačkinaitė et al., 2006; Mankevičienè et al., 2007; Dabkevičius et al., 2008; Kačergius et al., 2008) show that Alternaria Nees, Fusarium Link, Penicillium Link and Drechslera S. Ito are the micromycetes most often isolated from grain. Besides, there are important soil-borne pathogens of eyespot (Pseudocercosporella herpotrichoides (Fron) Deighton), take-all disease (Gaeumannomyces graminis (Sacc.) Arx \& D.L. Olivier) and snow mould (Monographella nivalis (Schaffnit) E. Müll.).

One of the alternatives for controlling root-zone pathogens of cereals is microbial biocontrol. Reports on search for micro-organisms that could control diseases are numerous and they vary greatly in their experimental design, plant pathogens, antagonistic microorganisms and host plants used. Research on biological control of plantpathogenic fungi in Lithuania so far has been associated exceptionally with antagonistic micromycetes of genus Trichoderma. These experiments resulted in patenting of T. harzianum C82-93 strain as a biocontrol agent against diseases caused by Fusarium, Botrytis cinerea (De Barry) Whetzel, Sclerotinia Fuckel, Cladosporium Link ex Fr. and Alternaria. Another Trichoderma strain T. viride M10 was produced for some time on an industrial scale as the 
biocontrol product "Trichoderminas". Both strains are primarily intended for disease suppression in vegetables, ornamentals and turfs, not cereal crops. Of the bacterial biocontrol agents there are products "Mycostop", "Cedomon" and "Cerall" currently registered as biopesticides on Lithuanian market, none of which are of local origin. "Mycostop" contains antagonistic strains of Streptomyces and is used for disease control in nursery gardens, vegetable, ornamentals and herbs production. "Cedomon" and "Cerall" are based on culture of Pseudomonas chlororaphis MA342 and are designed for seed-dressing of spring and winter cereals against seedborne diseases. Despite the fact that commercial biocontrol products are available for cereal crop protection, microorganisms of local origin are considered to be better suited for this purpose. This is based on the assertion that native micro-organisms are already adapted to climate in the area, and therefore their performance should not be thwarted by unfavourable abiotic conditions (Khan et al., 2010; Khan, 2013).

Conventionally search for biocontrol agents starts in a laboratory with in vitro experiments, continues with greenhouse or other small scale trials involving host plants, and then successful micro-organisms can be transferred to large scale field trials where economic and ecological benefits of biocontrol can be demonstrated. Due to the lack of direct link between successful in vitro testing and field trials, laboratory experiments are not necessarily performed in the screening process. In most initial screening trials, potential biocontrolling micro-organisms are tested either against solitary strains of different pathogen species (He et al., 2008; Alamri et al., 2012; Yoshida et al., 2012) or against a number of strains belonging to one or few related pathogen species (Laitila et al., 2002; Cavaglieri et al., 2004; Kildea et al., 2008). In the first case possible resistance/susceptibility of particular pathogen strain used is ignored, while the other strategy may give satisfactory results in areas where one disease is dominant. Studies of broad-spectrum antagonists when potential biocontrol agents are tested against numerous strains of numerous pathogen species/ genera are relatively few (Bacon et al., 2001; Johansson et al., 2003; Khan et al., 2006).

With no particular disease to be targeted as dominant, we have chosen to begin our search for biocontrolling microbes with isolation of common seedborne and soil-borne plant pathogens, form a set representing natural contamination of grain, and test it against a number of micro-organisms from rhizosphere of cereals.

\section{Materials and methods}

The micromycete isolation and identification trials were carried out in 2008-2009 at the Department of Plant Pathology and Protection, Lithuanian Institute of Agriculture (currently - Institute of Agriculture, Lithuanian Research Centre for Agriculture and Forestry), and Laboratory of Phytopathogenic Microorganisms, Lithuanian Institute of Botany (currently - Institute of Botany, Nature Research Centre). The isolation and identification of bacteria and the antifungal testing were performed in 2009 at Department of Microbiology and Biotechnology, Vilnius University.

Isolation and identification of fungi. All the micromycete cultures were isolated from the grain samples of cereal plants (spring wheat, spring barley, rye, triticale and oat) and rhizosphere of cereal plants (wheat and barley) collected in several locations in Lithuania. For the isolation of the internal mycobiota, 18 samples of cereal grains were surface-disinfected in 3\% aqueous solution of sodium hypochlorite for 2 minutes, rinsed twice with sterile distilled water and dried in laminar flow. 100 grains per sample were placed, 10 grains per Petri dish (Ǿ $100 \mathrm{~mm}$ ) on malt extract agar (MEA) ("Merck", Germany) amended with chloramphenicol $\left(50 \mathrm{mg} \mathrm{l}^{-1}\right)$. For the isolation of rhizosphere pathogens, three samples of plant roots were directly inoculated into MEA. The plates were incubated in the dark at $25^{\circ} \mathrm{C}$ for 5-7 days and resulting fungal colonies sub-cultured onto MEA. Isolates were identified according to the following authorities: Ellis (1971; 1976), Arx von (1981), Nelson et al. (1983), Watanabe (2002), Leslie, Summerell (2006) and Simmons (2007). Critical isolates were identified by taxon-specific polymerase chain reaction (PCR) (Kačergius, Mačkinaite, 2005). In further experiments fungi from this trial were used except for type strain Gaeumannomyces graminis var. graminis DSM1463.

Isolation of bacteria. Microbial cultures were isolated from the agricultural soil of Lithuanian Institute of Agriculture's experimental fields. Micro-organisms were isolated by suspending $1 \mathrm{~g}$ of soil in $100 \mathrm{ml}$ $0.85 \% \mathrm{NaCl}$ in Erlenmeyer flask and agitated at room temperature with rotation speed at $130 \mathrm{r} \mathrm{min}^{-1}$ for $4 \mathrm{~h}$. The suspensions were diluted tenfold up to $1: 10^{6}$ with $0.85 \% \mathrm{NaCl} .100 \mu \mathrm{l}$ of each dilution were poured into Petri dishes containing plate count agar (PCA) ("Merck"). After 12,18 and $72 \mathrm{~h}$ of cultivation at $30^{\circ} \mathrm{C}$ under aerobic conditions, morphologically distinct micro-organism colonies were picked and sub-cultivated on PCA to obtain pure cultures. The ability of isolated microbial cultures to grow on potato dextrose agar (PDA) ("Merck") at $25^{\circ} \mathrm{C}$ temperature was tested prior to testing of their antifungal activity. All the microbial isolates that were not culturable in these conditions were discarded, and the remaining 214 isolates were used in the antifungal testing.

Antifungal activity testing of bacterial isolates. PDA media was used for sub-cultivation of micromycete strains and bacterial antifungal activity testing. Ability of bacterial isolates to suppress micromycete culture growth was determined by thrusting a piece of mycelium of 1 of 
8 fungal strains (Bipolaris sorokiniana E197, Drechslera sp. E195, Fusarium anthophilum E147, F. culmorum E213, F. sambucinum E177, F. sporotrichioides E208, F. tricinctum E260 and Rhizoctonia solani E222) into the centre of Petri dish, cultivating at $25^{\circ} \mathrm{C}$ for $1-3$ days to reach a diameter of $\sim 2.5 \mathrm{~cm}$ and then stroking four different micro-organism cultures around the micromycete (Fig. 1).

The ability to suppress growth was determined visually after $2-5$ days of incubation at $25^{\circ} \mathrm{C}$. Active microbe isolates were tested against 35 additional plant-pathogenic fungal strains: Alternaria alternata E200 and E240, A. graminicola E244 and E275, Bipolaris sorokiniana E233 and E236, Cladosporium cladosporioides E218, Drechslera avenacea E242, D. biseptata E203, Drechslera sp. E201, E202, E220, E235 and E243, Fusarium anthophilum E155 and E133, F. avenaceum E199 and P30, F. culmorum E158, E172, E216 and E229, F. poae E212 and E219, F. sambucinum E124, F. sporotrichioides E210 and E214, Fusarium sp. E138, E211, E221 and E225, G. graminis var. graminis DSM1463, Monographella nivalis P07, Phialophora sp. P02 and Rhizoctonia solani E223. Fungal cultures were inoculated into growth media $\sim 2 \mathrm{~cm}$ from the edge of a Petri dish, cultivated at $20-25^{\circ} \mathrm{C}$ for $1-3$ days until fungal growth could be seen and then single microorganism culture was stroked onto the centre of a dish. In the control sample no micro-organism culture was added. Growth suppression was observed visually after $2-15$ days of incubation at $20-25^{\circ} \mathrm{C}$. All the samples of antifungal testing were carried out in triplicate.

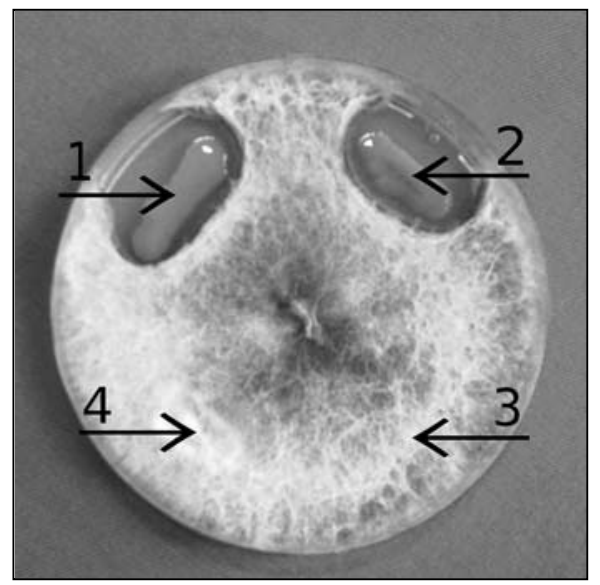

Notes. Micromycete culture Fusarium sambucinum E177 growing from the centre of Petri dish, rounded by four microbial isolates: MBK-v1 (arrow 1), MBK-v3 (2), MBK-v4 (3) and MBK-v6 (4). Strains (1) and (2) were selected for further testing.

Figure 1. Example of the initial antifungal testing sample

Phylogenetic analysis of bacterial isolates. The genomic deoxyribonucleic acid (DNA) of 10 most active bacterial cultures was isolated using the "Genomic DNA Extraction Kit" ("Fermentas", Lithuania). Presence of genomic DNA was confirmed by gel-electrophoresis in $0.8 \%$ agarose. Polymerase chain reaction was carried out using universal bacterial $16 \mathrm{~S}$ rDNA primers $27 \mathrm{f}$ (5'-GAGAGTTTGATCCTGGCTCAG-3') and 1495r (5'-CTACGGCTACCTTGTTACGA-3') (Weisburg et al., 1991). Amplification reactions were performed in an "Eppendorf ${ }^{\text {TM }}$ PCR" system using the following cycling parameters: $95^{\circ} \mathrm{C}$ for $2 \mathrm{~min}$; followed by 29 cycles of: $95^{\circ} \mathrm{C}$ for $1 \mathrm{~min}, 50^{\circ} \mathrm{C}$ for $2 \mathrm{~min}$ and $72^{\circ} \mathrm{C}$ for $3 \mathrm{~min}$; followed by final extension at $72^{\circ} \mathrm{C}$ for $7 \mathrm{~min}$. Presence of PCR products was confirmed by gel-electrophoresis in $1 \%$ agarose. The products were purified from PCR mix using a "DNA Purification Kit" ("Fermentas"). The protocol "BigDye Terminator v3.1 Cycle Sequencing Kit" ("Applied Biosystems", The Netherlands) was used for sequencing with genetic analyser 3130xl ("Applied Biosystems"). Sequences were compared to National Center for Biotechnology Information microbial genome database from Genomic BLAST services using programme MegaBLAST. All nucleotide sequences have been deposited in the National Center for Biotechnology Information GenBank. Accession numbers are: JQ729676 (MBK-s5), JQ729677 (MBK-d2), JQ729678 (MBK-d24), JQ729679 (MBK-r14), JQ729680 (MBK-z1), JQ773434 (MBK-r4), JQ773435 (MBK-v1), JQ773436 (MBK-v3), JQ773437 (MBK-v18), JQ773438 (MBK-a3).

\section{Results}

Isolation and identification of plant-pathogenic micromycetes. A total of 1037 seed-borne fungal cultures were isolated during this experiment. Taxonomic analysis showed that members of genus Alternaria were dominant, comprising $69.72 \%$ of the total internal grain mycobiota. Other genus of dematiaceous fungi Ulocladium accounted for $13.88 \%$ (Fig. 2).

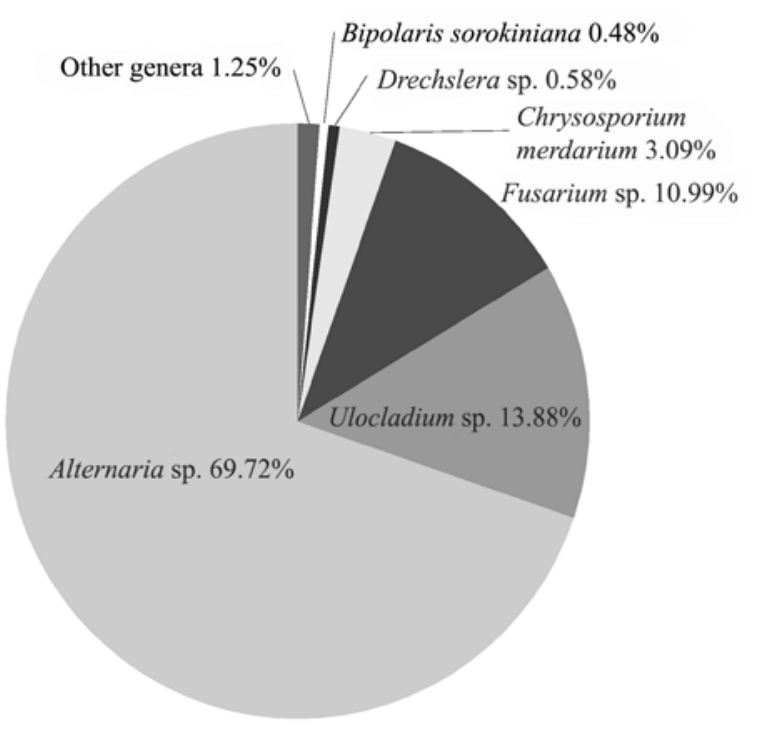

Figure 2. Taxonomic distribution of internal grain mycobiota, $\mathrm{n}=1037$ 
Important cereal crop pathogens Bipolaris sorokiniana and Drechslera spp. were comparatively rare and accounted for $0.48 \%$ and $0.58 \%$ respectively of the total internal grain mycobiota.

Eleven strains of pathogenic micromycetes were isolated from the plant root and rhizosphere. Alternaria and Fusarium were dominant among these isolates, together with one of the most harmful winter grain crop pathogens, Monographella nivalis. Another major pathogen, Gaeumannomyces graminis, was not isolated during this experiment, and therefore the type strain G. graminis var. graminis DSM1463 was used in the antagonistic trials.

Isolation and antifungal testing of bacterial cultures. A total of 214 microbial cultures, capable of growing on PDA at $25^{\circ} \mathrm{C}$ were isolated. In the initial stage of antifungal testing, 31 strains that were not overgrown or inhibited growth of at least one micromycete were selected for second-round antifungal testing against additional 35 plant pathogenic fungi. 10 bacterial strains were capable of suppressing growth of more than a half of fungal cultures they were tested against, these are: MBK-a3, MBK-r4, MBK-r14, MBK-v1, MBK-v3, MBK-v18, MBK-z1, MBK-d2, MBK-d24 and MBK-s5. Except for the strain MBK-r14, a clear, variable in size halo zone between suppressed pathogen and antagonist was observable in all the positive antifungal testing samples. There was no taxon-specific antifungal activity observed among 10 most active bacterial strains: if the bacterial strain was effective or ineffective against multiple micromycete cultures, these were of different fungal species or genera (Table 1).

Table 1. Antifungal efficiency of 10 most active bacterial strains and the list of micromycetes they were ineffective against

\begin{tabular}{|c|c|c|}
\hline Strain & $\begin{array}{l}\text { Effectiveness } \\
\text { against } 43 \\
\text { tested fungi \% }\end{array}$ & Ineffective against \\
\hline MBK-a3 & 90.7 & Fusarium avenaceum $\mathrm{P} 30$, F. culmorum E216, Rhizoctonia solani $\mathrm{E} 222$ and E223 \\
\hline MBK-d2 & 95.4 & F. sambucinum E177, F. sporotrichioides E208 \\
\hline MBK-d24 & 86.1 & $\begin{array}{l}\text { Drechslera sp. E201, F. culmorum E158 and E216, F. sambucinum E177, } \\
\text { F. sporotrichioides E208 and E210 }\end{array}$ \\
\hline MBK-r4 & 100 & - \\
\hline MBK-r14 & 79.1 & $\begin{array}{l}\text { F. anthophilum E147, F. avenaceum P30, F. culmorum E158, F. sporotrichioides E208, E210 and } \\
\text { E214, Fusarium sp. E211, R. solani E222 and E223 }\end{array}$ \\
\hline MBK-s5 & 98.4 & F. avenaceum $\mathrm{P} 30$ \\
\hline MBK-v1 & 93 & F. poae E212, F. sporotrichioides E208, Fusarium sp. E211 \\
\hline MBK-v3 & 93 & F. culmorum E216, F. sambucinum E124 and E177 \\
\hline MBK-v18 & 53.5 & $\begin{array}{l}\text { Alternaria alternata } \mathrm{E} 200 \text { and E240, A. graminicola E244 and E275, } \\
\text { F. anthophilum E133, E147 and E155, F. poae E212 and E219, F. culmorum E158, E172, E213, } \\
\text { E216 and E229, F. sporotrichioides E208, F. tricinctum E260, Fusarium sp. E138, E211 and E221, } \\
\text { Phialophora sp. P02 }\end{array}$ \\
\hline MBK-z1 & 83.7 & $\begin{array}{l}\text { Bipolaris sorokiniana } \mathrm{E} 197, \text { F. culmorum } \mathrm{E} 216 \text { and } \mathrm{E} 158, \text { F. avenaceum } \mathrm{P} 30 \text {, } \\
\text { F. poae } \mathrm{E} 212, \text { F. sporotrichioides } \mathrm{E} 208 \text { and } \mathrm{E} 210\end{array}$ \\
\hline
\end{tabular}

Some fungal strains appear more frequently than others in Table 1, and this could mean a higher resistance level of these micromycetes. Twenty one remaining second-step antifungal testing bacterial strains had antagonistic activity against 1 to 4 micromycete strains of total 43. Strains B. sorokiniana E197, Phialophora sp. P02 and $F$. tricinctum E260 were suppressed more often than other fungal strains - by 26, 22 and 21 of total 31 second-step trial bacterial antagonists, respectively.
Phylogenetic analysis of most active bacterial strains. The BLAST analysis of sequenced $16 \mathrm{~S}$ rDNA genes of the microbial strains showed that 7 of 10 selected strains are of the bacterial genus Bacillus, 2 strains - of genus Serratia, and 1 strain was shown to be of genus Pseudomonas (Table 2).

The affiliation of single Pseudomonas isolate MBK-v18 could not be determined accurately because the closest non-typical and typical strains from GenBank, 
Table 2. Approximate phylogenetic position of the 10 most active bacterial strains

\begin{tabular}{|c|c|c|c|c|c|c|}
\hline Strain & $\begin{array}{l}\text { Three most similar sequences } \\
\text { from GenBank }\end{array}$ & $\begin{array}{l}\text { Sequence } \\
\text { identity } \\
\%\end{array}$ & Accession number & $\begin{array}{l}\text { Most similar type } \\
\text { culture sequence }\end{array}$ & $\begin{array}{l}\text { Sequence } \\
\text { identity } \\
\%\end{array}$ & Accession number \\
\hline $\begin{array}{l}\text { MBK-a3 } \\
\text { MBK-d2 } \\
\text { MBK-d24 }\end{array}$ & $\begin{array}{l}\text { Bacillus subtilis subsp. subtilis } \\
\text { SC-8 92_1 } \\
\text { B. subtilis subsp. subtilis SMY } \\
\text { B. subtilis subsp. subtilis JH642 }\end{array}$ & $\begin{array}{l}100 \\
100\end{array}$ & $\begin{array}{l}\text { AGFW01000001.1 } \\
\text { ABQN01000001.1 } \\
\text { ABQM01000001.1 }\end{array}$ & $\begin{array}{l}\text { Bacillus subtilis } \\
\text { subsp. subtilis } \text { str. } \\
\text { NCIB } 3610\end{array}$ & 100 & ABQL01000001.1 \\
\hline $\begin{array}{l}\text { MBK-r4 } \\
\text { MBK-z1 }\end{array}$ & $\begin{array}{l}\text { B. subtilis subsp. subtilis } \\
\text { SC-8 92_1 } \\
\text { B. subtilis subsp. subtilis SMY } \\
\text { B. subtilis subsp. subtilis JH642 }\end{array}$ & $\begin{array}{l}99 \\
99\end{array}$ & $\begin{array}{l}\text { AGFW01000001.1 } \\
\text { ABQN01000001.1 } \\
\text { ABQM01000001.1 }\end{array}$ & $\begin{array}{l}\text { B. subtilis subsp. } \\
\text { subtilis str. } \\
\text { NCIB } 3610\end{array}$ & 99 & ABQL01000001.1 \\
\hline MBK-r14 & $\begin{array}{l}\text { B. pseudomycoides DSM12442 } \\
\text { B. mycoides Rock3-17 } \\
\text { B. mycoides Rock1-4 }\end{array}$ & $\begin{array}{l}99 \\
99 \\
99\end{array}$ & $\begin{array}{l}\text { ACMX01000133.1 } \\
\text { ACMW01000221.1 } \\
\text { ACMV01000354.1 }\end{array}$ & $\begin{array}{c}B . \\
\text { pseudomycoides } \\
\text { DSM12442 }\end{array}$ & 99 & ACMX01000133.1 \\
\hline MBK-s5 & $\begin{array}{l}\text { B. thuringiensis } \text { IBL } 4222 \\
\text { B. thuringiensis serovar berliner } \\
\text { ATCC } 10792 \\
\text { B. thuringiensis serovar } \\
\text { thuringiensis } \text { str. T01001 }\end{array}$ & $\begin{array}{l}100 \\
100 \\
100\end{array}$ & $\begin{array}{l}\text { ACNL01000301.1 } \\
\text { ACNF01000156.1 } \\
\text { ACNA01000167.1 }\end{array}$ & $\begin{array}{l}\text { B. thuringiensis } \\
\text { serovar berliner } \\
\text { ATCC } 10792\end{array}$ & 100 & ACNF01000156.1 \\
\hline $\begin{array}{l}\text { MBK-v1 } \\
\text { MBK-v3 }\end{array}$ & $\begin{array}{l}\text { Serratia odorifera } \\
\text { 4Rx13 SODg } \\
\text { Serratia } \text { sp. AS12 } \\
\text { Serratia } \text { sp. AS9 }\end{array}$ & $\begin{array}{l}99 \\
99\end{array}$ & $\begin{array}{l}\text { ADBX01000007.1 } \\
\text { NC_015566.1 } \\
\text { NC_015567.1 }\end{array}$ & $\begin{array}{l}\text { Serratia odorifera } \\
\quad \text { DSM4582 }\end{array}$ & 98 & ADBY01000001.1 \\
\hline MBK-v18 & $\begin{array}{c}\text { Pseudomonas putida } \mathrm{W} 619 \\
\text { P. putida } \mathrm{GB}-1 \\
\text { P. putida } \mathrm{F} 1\end{array}$ & $\begin{array}{l}99 \\
99 \\
99\end{array}$ & $\begin{array}{l}\mathrm{NC} \_010501.1 \\
\mathrm{NC} \_010322.1 \\
\mathrm{NC} \_009512.1\end{array}$ & $\begin{array}{l}\text { Pseudomonas } \\
\text { stutzeri } \\
\text { ATCC } 17588\end{array}$ & 97 & NC_015740.1 \\
\hline
\end{tabular}

P. putida and $P$. stutzeri, respectively belong to phylogenetically distinct groups of genus Pseudomonas. Also strain MBK-a3 possesses uncommon for the $B$. subtilis red pigment synthesis ability, and strains MBK-v1 and MBK-v3 lack the potato-like odour typical of $S$. odorifera species, so the systematic position of these isolates still needs to be clarified.

\section{Discussion}

The results of seed-borne cereal pathogen isolation and identification were similar to previously published experimental results (Kačergius, Mačkinaitè, 2005; Mačkinaitė et al., 2006; Mankevičienè et al., 2007; Dabkevičius et al., 2008; Kačergius et al., 2008), where cultures of genera Alternaria, Fusarium and Ulocladium were dominant, but in our trial Drechslera spp. and Bipolaris sorokiniana were isolated at significantly lower rates. Most likely because of the grain surface sterilization we did not isolate any Penicillium, which is considered more of a surface inhabiting production spoiler, not a plant pathogen. However, other studies on micromycete distribution in grain (Mankevičienè et al., 2007; Dabkevičius et al., 2008) involve isolation of fungi from non-sterilized grain surface and in these experiments isolation of Penicillium was very common.
In general, the results of fungi isolation and identification do not differ significantly from previous experiments of this kind, but in our case screening for biocontrol agents should benefit from being done against the common pathogens and should be viewed as representation of natural contamination of grain.

The micromycete cultures for antifungal testing were selected with the emphasis on major pathogens (Fusarium, Drechslera, Bipolaris, Rhizoctonia and Monographella) and included relatively fewer strains of fungi that were isolated at higher rates (Fig. 2), but usually do not cause great damage in fields (Alternaria and Ulocladium). This was also the reason for adding G. graminis var. graminis strain DSM1463 to antifungal testing, even though we did not isolate this pathogen.

Dual culture method may not be the best choice for initial antagonist screening because it eliminates host plant and environment factors and it is most likely to detect only direct antagonism by antibiosis (Khan, 2013), but also it is much less time and resource demanding in comparison to screening strategies involving more components, and when conducting a trial with large collections of bacteria and fungal pathogens of multiple host plant species like in our study, this method becomes a reasonable approach. 
The most important finding from antifungal testing was the great variation of suppressive activity expressed by bacterial antagonists against micromycete strains of the same species or genera. Similar observations were made by other studies (Laitila et al., 2002; Cavaglieri et al., 2004), where in a number of the same species pathogen strains susceptibility to antagonistic microorganisms varied. This should put to question screening strategies with the solitary strains of particular pathogen species used.

The 5 of 10 most active bacterial strains are closely related to most established microbial biocontrol agent species B. subtilis (Nagorska et al., 2007; Ongena, Jacques, 2007). Other strains were shown to be related to non-conventional microbial biocontrol bacteria. Though systematic position of the Pseudomonas strain MBK-v18 could not be determined accurately, being close to nontypical strains of $P$. putida could be a sign of potential use as a biological control agent (Haas, Defago, 2005). Strain MBK-s5 is related to strains of $B$. thuringiensis, which is well-known as biopesticide against insect vermin, not pathogenic micromycetes, and it would be interesting if activity of this particular isolate against insects could be demonstrated. Somewhat new bacteria in the field of biological control are B. mycoides/B. pseudomycoides (strain MBK-r14) and Serratia odorifera (strains MBK-v1 and MBK-v3). The first one has a distinctive frost-like growth on solid media and is mentioned in literature on biological control as an antagonist of Botrytis cinerea Pers. (Guetsky et al., 2002). S. odorifera strains were reported to be used in biocontrol experiments, but they inhibited growth of plant pathogens as well as plants they were tested on (Vespermann et al., 2007).

With an exception of B. mycoides/B. pseudomycoides, all of the above mentioned bacterial species are known as antibiotic compound producers (Haas, Defago, 2005; Ongena, Jacques, 2007; Vespermann et al., 2007). A clear halo zone in our antifungal testing samples indicates possible antibiotic production by these bacterial isolates and detection of these compounds together with field experiments are the next steps of research concerning these bacteria.

\section{Conclusions}

1. Results of isolation of internal grain mycobiota correlate with previously described experiments of this kind: the dominant fungal genera are Alternaria, Fusarium and Ulocladium.

2. Determination of systematic position of 10 most active bacterial strains shows that 7 of them are closely related to well-known biocontrol agents Bacillus subtilis, B. thuringiensis and Pseudomonas spp., while 3 remaining strains of $B$. mycoides/B. pseudomycoides and Serratia odorifera are not considered established organisms in the field of microbial biocontrol.
3. The tested bacterial isolates expressed no taxon-specific antifungal activity.

4. Fungal strains with enhanced susceptibility to bacterial presence were identified. These strains should be avoided in screening for bacteria with antifungal activity.

\section{Acknowledgements}

This work was supported by the Lithuanian Research Council program "Lithuania's scientific research and experimental development 2008-2010", project "Prokaryotes for ecological agriculture efficiency and food safety production development (PROKTECHAS)".

Received 22052013

Accepted 06122013

\section{References}

Alamri S., Hashem M., Mostafa Y. S. 2012. In vitro and in vivo biocontrol of soil-borne phytopathogenic fungi and their possible mode of action. Biocontrol Science, 17 (4): 155167 http://dx.doi.org/10.4265/bio.17.155

Arx von J. A. 1981. The genera of fungi sporulating in pure culture. Vaduz, Liechtenstein

Bacon C. V., Yates I. E., Hinton D. M., Meredith F. 2001. Biological control of Fusarium moniliforme in maize. Environmental Health Perspectives, 109 (2): 325-332 http://dx.doi.org/10.1289/ehp.01109s2325

Cavaglieri L., Passone A., Etcheverry M. 2004. Screening procedures for selecting rhizobacteria with biocontrol effects upon Fusarium verticillioides growth and fumonis in B1 production. Research in Microbiology, 155: 747-754 http://dx.doi.org/10.1016/j.resmic.2004.06.001

Dabkevičius Z., Sinkevičienė J., Semaškienè R., Sirvydas A., Kerpauskas P. 2008. The effect of thermal treatment of spring barley seed infection and germination. ZemdirbysteAgriculture, 95 (4): 172-182

Ellis M. B. 1971. Dematiaceous hyphomycetes. London, UK

Ellis M. B. 1976. More dematiaceous hyphomycetes. London, UK

Guetsky R., Shtienberg D., Elad Y., Fisher E., Dinoor A. 2002. Improving biological control by combining biocontrol agents each with several mechanisms of disease suppression. Phytopathology, 92 (9): 976-985 http://dx.doi.org/10.1094/PHYTO.2002.92.9.976

Haas D., Defago G. 2005. Biological control of soil-borne pathogens by fluorescent pseudomonads. Nature Reviews in Microbiology, 3 (4): 307-319 http://dx.doi.org/10.1038/nrmicro1129

He J., Boland G.J., Zhou T. 2008. Concurrent selection for microbial suppression of Fusarium graminearum, Fusarium head blight and deoxynivalenol in wheat. Journal of Applied Microbiology, 106 (6): 1805-1817 http://dx.doi.org/10.1111/j.1365-2672.2009.04147.x 
Johansson P. M., Johnsson L., Gerhardson B. 2003. Suppression of wheat-seedling diseases caused by Fusarium culmorum and Microdochium nivale using bacterial seed treatment. Plant Pathology, 52 (2): 219-227 http://dx.doi.org/10.1046/j.1365-3059.2003.00815.x

Kačergius A., Mačkinaitė R. 2005. PCR-based detection and identification of fungi producing trichotecenes in food grains. Botanica Lithuanica, 11 (2): 87-99

Kačergius A., Drik I., Supronienè S. 2008. Distribution of fusaria in Lithuanian food grain in 2005-2007. Acta Microbiologica et Immunologica Hungarica, 55 (2): 204-205

Khan R. M. 2013. Beneficial bacteria for biological control of fungal pathogens of cereals. Maheshwari D. K. (ed.). Bacteria in agriculture: disease management, p. 153-165

Khan M. R., Fisher S., Egan D., Doohan F. M. 2006. Biological control of Fusarium seedling blight disease of wheat and barley. Phytopathology, 96 (4): 386-394 http://dx.doi.org/10.1094/PHYTO-96-0386

Khan M. R., Brien E. O., Carney B. F., Doohan F. M. 2010. A fluorescent Pseudomonas shows potential for the control of net blotch disease of barley. Biological Control, 54: 41-45 http://dx.doi.org/10.1016/j.biocontrol.2010.02.010

Kildea S., Ransbotyn V., Khan M. R., Fagan B., Leonard G., Mullins E., Doohan F. M. 2008. Bacillus megaterium shows potential for the biocontrol of Septoria tritici blotch of wheat. Biological Control, 47: 37-45 http://dx.doi.org/10.1016/j.biocontrol.2008.07.001

Laitila A., Alakomi H.-L., Raaska L., Mattila-Sandholm T. Haikara A. 2002. Antifungal activities of two Lactobacillus plantarum strains against Fusarium moulds in vitro and in malting of barley. Journal of Applied Microbiology, 93: 566-576 http://dx.doi.org/10.1046/j.1365-2672.2002.01731.x

Leslie J. F., Summerell B. A. 2006. The Fusarium laboratory manual. Oxford, UK http://dx.doi.org/10.1002/9780470278376

Mačkinaitė R., Kačergius A., Lugauskas A., Repečkienė J. 2006. Contamination of cereal grain by Fusarium micromycetes and their mycotoxins under Lithuanian climatic conditions. Ekologija, 52 (3): 71-79

Mankevičienė A., Supronienė S., Dabkevičius Z., Mačkinaitė R. 2007. The occurrence of fungi and mycotoxyn content in winter wheat grain in relation to harvesting time. Zemdirbyste-Agriculture, 94 (3): 162-175

Nagorska K., Bilkowski M., Obuchowski M. 2007. Multicellular behaviour and production of a wide variety of toxic substances support usage of Bacillus subtilis as a powerful biocontrol agent. Acta Biochimica Polonica, 54 (3): 495-508

Nelson P. E., Toussoun T. A., Marasas W. F. O. 1983. Fusarium species: an illustrated manual for identifi cation. University Park, Pennsylvania, USA
Ongena M., Jacques P. 2007. Bacillus lipopeptides: versatile weapons for plant disease biocontrol. Trends in Microbiology, 16 (3): 115-126 http://dx.doi.org/10.1016/j.tim.2007.12.009

Simmons E. G. 2007. Alternaria: an identification manual: fully illustrated and with catalog raisonné 1796-2007. Fungal Biodiversity Centre, Utrecht, the Netherlands

Vespermann A., Kai M., Piechulla B. 2007. Rhizobacterial volatiles affect the growth of fungi and Arabidopsis thaliana. Applied and Environmental Microbiology, 73 (17): 5639-5641 http://dx.doi.org/10.1128/AEM.01078-07

Watanabe T. 2002. Pictorial atlas of soil and seed fungi: morphologies of cultured fungi and key to species ( $2^{\text {nd }} \mathrm{ed}$.). Boca Raton, USA

Weisburg W. G., Barns S., M., Pelletier D. A., Lane D. J. 1991. 16S ribosomal DNA amplification for phylogenetic study. Journal of Bacteriology, 173: 697-703

Yoshida S., Ohba A., Liang Y. M., Koitabashi M., Tsushima S. 2012. Specificity of Pseudomonas isolates on healthy and Fusarium head blight-infected spikelets of wheat heads. Microbial Ecology, 64 (1): 214-225 http://dx.doi.org/10.1007/s00248-012-0009-y 
ISSN 1392-3196 / e-ISSN 2335-8947

Zemdirbyste-Agriculture, vol. 101, No. 2 (2014), p. 185-192

DOI 10.13080/z-a.2014.101.024

\title{
Dauginiu antagonistiniu poveikiu javų patogeniniams mikromicetams pasižyminčios bakterijos
}

\author{
S. Sakalauskas ${ }^{1,3}$, A. Kačergius ${ }^{2}$, D. Janušauskaitè ${ }^{3}$, D. Čitavičius ${ }^{1}$ \\ ${ }^{1}$ Vilniaus universitetas \\ ${ }^{2}$ Lietuvos agrarinių ir miškų mokslų centro Vokès filialas \\ ${ }^{3}$ Lietuvos agrarinių ir miškų mokslų centro Žemdirbystès institutas
}

\section{Santrauka}

Vyraujančių javų patogenų priklausymas skirtingoms mikromicetų sistematinėms grupėms yra jų biologinės kontrolès priemonių paiešką sunkinantis veiksnys. Vienas šios problemos sprendimo būdų yra plataus spektro antagonistiniu poveikiu pasižyminčių mikroorganizmų paieška ir jų pritaikymas javų kultūrų apsaugai. Tyrimų metu iš įvairių grūdinių kultūrų buvo išskirti 1037 su sẻkla plintantys ir 11 pašaknio zonos patogeninių mikromicetų, nustatyta jų sistematinè padètis. Lyginant su ankstesnių panašių Lietuvoje atliktų tyrimų duomenimis, didelių skirtumų nenustatyta: tarp išskirtų kamienų dominavo Alternaria, Ulocladium ir Fusarium genčių grybai, tačiau išskirta palyginus nedaug Drechslera ir Bipolaris sorokiniana izoliatų. Iš išskirtų grybų atrinkti 42 kamienai ir prie jų pridètas Gauemannomyces graminis var. graminis DSM1463 kamienas buvo panaudoti kaip testinès kultūros, tiriant 214 iš dirbamų laukų dirvos išskirtų mikroorganizmų izoliatų antagonistinị poveikị in vitro. Tyrimų metu atrinkta 10 bakterijų kamienų, pasižymèjusių antagonistiniu poveikiu daugiau nei pusei iš 43 tirtų mikromicetų kultūrų. Palyginus 16S rDNR genų sekas nustatyta aktyviausių bakterijų kamienų sistematinè padètis: 7 iš 10 kamienų priklauso Bacillus genčiai, iš kurių 5 artimiausios B. subtilis rūšiai, po 1 - B. thuringiensis ir B. mycoides arba $B$. pseudomycoides rūšims. Likę 3 aktyvių bakterijų kamienai priklauso Serratia ir Pseudomonas gentims, iš jų 2 artimi $S$. odorifera rūšiai.

Reikšminiai žodžiai: antibiozè, bakterijos, dauginis antagonizmas, javų ligos, patogeniniai mikromicetai. 